\title{
Effect of Plant Hormones and Distillation Water on Mints
}

\author{
Valtcho D. Zheljazkov ${ }^{1,5}$ \\ Mississippi State University, North Mississippi Research and Extension \\ Center, 5421 Highway 145 South, Verona, MS 38879
}

Tess Astatkie ${ }^{2}$

Department of Engineering, Nova Scotia Agricultural College, 50 Pictou Road, P.O. Box 550, Truro, NS B2N 5E3, Canada

\section{Thomas Horgan ${ }^{3}$ and S. Marie Rogers ${ }^{4}$ \\ Mississippi State University, North Mississippi Research and Extension Center, 5421 Highway 145 South, Verona, MS 38879}

Additional index words. Mentha $\times$ piperita, 'Black Mitcham' peppermint, Mentha spicata, 'Native' spearmint, essential oil content, oil composition

\begin{abstract}
Steam distillation of essential oil crops produces residual distillation wastewater that is released into the environment. This study evaluated the effects of three plant hormones [methyl jasmonate (MJ); gibberellic acid (GA3); and salicylic acid (SA)] at three concentrations and the residual distillation water from 15 plant species applied as foliar spray on biomass yields, essential oil content, and essential oil yield of Mentha ×piperita 'Black Mitcham' and Mentha spicata 'Native'. Overall, the application of SA at $1000 \mathrm{mg} \cdot \mathrm{L}^{-1}$ increased biomass yields of both species. More treatments influenced essential oil content in 'Black Mitcham' peppermint than in 'Native' spearmint. Application of MJ at 100 and $1000 \mathrm{mg} \cdot \mathrm{L}^{-1}, \mathrm{GA3}$ at $10 \mathrm{mg} \cdot \mathrm{L}^{-1}, \mathrm{SA}$ at $10 \mathrm{or} 100 \mathrm{mg} \cdot \mathrm{L}^{-1}$, and distillation water of Achillea millefolium, Ammi majus, Artemisia absinthium, Cymbopogon flexuosus, Cymbopogon martinii, Chrysanthemum balsamita, and Hypericum perforatum increased the essential oil content of peppermint, whereas the oil content of spearmint was increased only by application of Monarda fistulosa distillation water. Application of $\mathrm{MJ}$ at $100 \mathrm{mg} \cdot \mathrm{L}^{-1}, \mathrm{SA}$ at $100 \mathrm{mg} \cdot \mathrm{L}^{-1}$, and $A$. absinthium, C. flexuosus, and C. balsamita distillation waters increased essential oil yields of peppermint, whereas the application of SA at $1000 \mathrm{mg} \cdot \mathrm{L}^{-1}$ and distillation water of $A$. absinthium, Lavandula vera, and $M$. fistulosa increased oil yields of spearmint. This study demonstrated that the residual distillation water of some aromatic plant species may be used as a tool for increasing essential oil content or essential oil yields of peppermint and spearmint crops.
\end{abstract}

In the process of extracting essential oil from aromatic plants through steam distillation, there is the production of waste distillation water, which is released into the environment (Lawrence, 2007; Topalov, 1989). The distillation water results from partial condensation of steam passing through the aromatic biomass. It is different from the hydrolat, the water eluted after separation of the essential oil, which is often reprocessed to recover traces of essential oil. Finding new uses for

Received for publication 14 May 2010. Accepted for publication 6 July 2010 .

This research was funded by ARS Specific Cooperative Agreement 58-6402-4-026 with CRIS MIS-172050 [research grant "Medicinal Herbs Research in Mississippi," awarded to Dr. Jeliazkov (Zheljazkov)].

Approved for publication as Journal Article No. J-11844 of the Mississippi Agricultural and Forestry Experment Station, Mississippi State University.

${ }^{1}$ Associate Research Professor.

${ }^{2}$ Professor.

${ }^{3}$ Research Associate.

${ }^{4}$ Extension Agent.

${ }^{5}$ To whom reprint requests should be addressed; e-mailvj40@pss.msstate.edu. this waste product would benefit essential oil crop growers and processors as well as the environment. It was shown that the distillation wastewater of sage, thyme, and rosemary contained antioxidants and could be used as an ingredient in marinades for turkey meat to inhibit lipid oxidation and the development of rancid off-flavors (Mielnik et al., 2008). We hypothesized that residual distillation water could have an effect on peppermint (Mentha xpiperita L.) and spearmint (Mentha spicata L.) plants when used as a foliar spray.

Peppermint and spearmint were chosen as test plants because these crops are the most widely grown essential oil crops both in the United States (Lawrence, 2007; National Agricultural Statistic Service, 2009) and worldwide (Lawrence, 2007). Moreover, the U.S. essential oil industry is aiming to expand the acreage of peppermint and spearmint in the South, triggering some recent studies in the southeastern United States (Zheljazkov et al., 2010a, 2010b). Commercially important peppermint products are the essential oil, dry leaves for the herbal tea market, and fresh herbage for the fresh herb market, whereas spearmint is used mostly for essential oil production and as a fresh culinary herb [Lawrence, 2007; Mint Industry Research Council (MIRC), 2009; Mustiatse, 1985; Topalov, 1989]. Peppermint and spearmint essential oils are used in chewing gum, toothpaste, mouthwashes, confectionaries, pharmaceuticals, and aromatherapy products (Lawrence, 2007; MIRC, 2009). If the distillation wastewater from an aromatic crop is shown to have growth-promoting effects on peppermint and spearmint or improve their essential oil content, such an extract could be applied to large-scale production systems, bringing significant economic benefits. Finding new uses of a waste product would also improve the environmental sustainability of the essential oil production industry.

\section{Materials and Methods}

Plant materials and growing conditions of the field experiment. The pot experiment was preceded by a field experiment in which 15 essential oil crops were grown in a randomized complete block in four replicates for one season, harvested, and extracted to obtain the distillation wastewater. The 15 essential oil crops were: wormwood, Artemisia absinthium L.; bishop's weed, Ammi majus L.; yarrow, Achillea millefolium L.; alecost, Chrysanthemum balsamita L.; lemon grass, Cymbopogon flexuosus (Nees ex Steud.) Will. Watson; palmarosa, Cymbopogon martinii (Roxb.) Wats.; hyssop, Hyssopus officinalis L.; St. John's wort, Hypericum perforatum L.; lavender, Lavandula vera D.C.; wild bergamot, Monarda fistulosa L.; shiso, Perilla frutescens (L.) Britton.; rue, Ruta graveolens L.; endemic Balkan winter savory, Satureja pilosa L.; Balkan sideritis, Sideritis scardica Griseb.; and feverfew, Tanacetum parthenium (L.) Sch. Bip. All 15 crops were grown under the same conditions on plastic-covered raised beds as described previously (Zheljazkov et al., 2008). After harvest, representative samples from the 15 crops were dried at a shady location, and subsamples of $300 \mathrm{~g}$ dried biomass from each crop in three replications were extracted by steam distillation. The steam distillation was performed for $60 \mathrm{~min}$ in $2-\mathrm{L}$ Clevenger-type distillation units as described previously (Zheljazkov et al., 2008), and the residual distillation water from each crop was collected and stored at $4{ }^{\circ} \mathrm{C}$ for use in the controlled environment experiment with spearmint and peppermint.

Controlled environment experiment. For the pot study we used certified virus-free material of 'Native' spearmint (Mentha spicata L.) and 'Black Mitcham' peppermint (Mentha xpiperita L.). Transplants (10 to $12 \mathrm{~cm}$ high with a couple of well-developed pairs of leaves) of both cultivars were obtained from the Summit Plant Laboratories, Inc. (Fort Collins, CO). Because of their hybrid nature, commercial varieties of spearmint and peppermint are propagated vegetatively (Lawrence, 2007; Tucker, 1992; Tucker and Fairbrothers, 1990). The container experiment was conducted in 3-gallon pots with $3.1 \mathrm{~kg}$ of commercial growth medium (Metromix 
300; Sun Gro Horticulture, Bellevue, WA) in each pot. In every pot, two plants were transplanted and grown for 4 months until harvest. The experiment was conducted in a controlled-environment greenhouse (22 to $25{ }^{\circ} \mathrm{C} / 18$ to $20{ }^{\circ} \mathrm{C}$ day/night temperature regime) with an individual drip-tape irrigation system and emitter in every pot. Nutrient application to each pot was equivalent to a field application of $\approx 240 \mathrm{~kg} \mathrm{~N} / \mathrm{ha}$. The design was a $2 \times 25$ factorial with three replications, making the total number of treatment combinations 50. Within each of the two species, Treatments 1 to 9 were the three plant hormones at three concentrations [methyl jasmonate (MJ) at 10, 100, and $1000 \mathrm{mg} \cdot \mathrm{L}^{-1}$; gibberellic acid (GA3) at 10,100 , and $1000 \mathrm{mg} \cdot \mathrm{L}^{-1}$; and salicylic acid (SA) at 10, 100, and 1000 $\mathrm{mg} \cdot \mathrm{L}^{-1}$ ]; Treatments 10 to 24 were the residual distillation water (extracts) from 15 essential oil crops; and Treatment 25 was the water control. We selected MJ, GA3, and SA as representative plant growth regulators from a large group of plant hormones.

The spearmint and peppermint plants in the controlled environment pot experiment were treated twice with hormone solutions and extracts: at the beginning of bud formation and again at the beginning of flowering. Each pot received $\approx 10 \mathrm{~mL}$ of solution or extract as a foliar spray at each treatment. Both mint species were harvested $7 \mathrm{~d}$ after the second treatment, when plants were blooming. Fresh biomass yields were recorded. After plants were dried at a shady location, the air-dried yields were recorded.

Essential oil extraction and analyses. The essential oil from the spearmint and peppermint from each pot was extracted with steam distillation as described previously (Zheljazkov et al., 2010a, 2010b), and the essential oil was collected and measured. The essential oil composition of each sample was analyzed on a Hewlett Packard 6890 gas chromatograph (Agilent Technologies, Palo Alto, CA) with an autosampler [carrier gas helium, $40 \mathrm{~cm} \cdot \mathrm{sec}^{-1} ; 11.7 \mathrm{psi}\left(60{ }^{\circ} \mathrm{C}\right) ; 2.5 \mathrm{~mL} \cdot \mathrm{min}^{-1}$ constant flow rate; injection: split $(60: 1)$, $0.5 \mu \mathrm{L}$, inlet $220^{\circ} \mathrm{C}$; oven temperature program: $60^{\circ} \mathrm{C}$ for $1 \mathrm{~min}, 10{ }^{\circ} \mathrm{C} / \mathrm{min}$ to $250{ }^{\circ} \mathrm{C}$; column: HP-INNOWAX (Agilent Technologies) (crosslinked polyethylene glycol), $30 \mathrm{~m} \times$ $0.32 \mathrm{~mm} \times 0.5 \mu \mathrm{m}$; flame ionization detector temperature $275^{\circ} \mathrm{C}$ ].

Statistical analyses. Dry weight and essential oil weight and content response measurements were analyzed as two-factor factorial of species (Mentha $\times$ piperita and M. spicata) and treatment (25 treatments). The analysis of variance was performed using the GLM Procedure of SAS (SAS Institute Inc., 2003), and further multiple means comparison was performed when the main effect or interaction with species effect of treatment was significant $(P<0.05)$ using the lsmeans statement of Proc GLM at $\alpha=0.01$ to protect against the overinflation of the Type I experimentwise error rate. For each response, the validity of model assumptions on the error terms was verified by examining the residuals as described in Montgomery (2009).

\section{Results and Discussion}

Statistical analysis indicated that the interaction effect of species and treatment was significant on oil content and oil yield, whereas only the main effects were significant on dry biomass yield (Table 1). With regard to biomass yield, the application of SA at $1000 \mathrm{mg} \cdot \mathrm{L}^{-1}$ increased yields of both mints relative to the control, whereas the other treatments were not significantly different from the control (Table 2 ). However, SA at only $10 \mathrm{mg} \cdot \mathrm{L}^{-1}$ gave the lowest biomass yield.

The essential oil content was higher in peppermint than in spearmint in most, but not all, cases (Table 2). The essential oil content of peppermint varied from $0.77 \%$ (in the $T$. parthenium treatment) to $1.55 \%$ (in the $\mathrm{MJ}$ $100 \mathrm{mg} \cdot \mathrm{L}^{-1}$ treatment), whereas the oil content of spearmint varied from $0.47 \%$ (in the GA3 $10 \mathrm{mg} \cdot \mathrm{L}^{-1}$ treatment) to $0.89 \%$ (in the M. fistulosa treatment). Treatments had different effects on the two mint species. For example, the application of $\mathrm{MJ}$ at $100 \mathrm{mg} \cdot \mathrm{L}^{-1}$ and $1000 \mathrm{mg} \cdot \mathrm{L}^{-1}, \mathrm{GA} 3$ at $10 \mathrm{mg} \cdot \mathrm{L}^{-1}$, SA at 10 and $100 \mathrm{mg} \cdot \mathrm{L}^{-1}$, and the distillation water of A. millefolium, A. majus, A absinthium, $C$. flexuosus, C. martinii, C. balsamita, and $H$. perforatum increased the essential oil content of peppermint, whereas the oil content of spearmint was increased only by the application of $M$. fistulosa distillation water. The overall essential oil weight (a function of biomass yields and essential oil content) were also differently affected by the treatments in the two mint species (Table 2). The application of $\mathrm{MJ}$ at $100 \mathrm{mg} \cdot \mathrm{L}^{-1}, \mathrm{SA}$ at $100 \mathrm{mg} \cdot \mathrm{L}^{-1}$, and A. absinthium, C. flexuosus, C. balsamita, and $R$. graveolens distillation waters increased essential oil weight of peppermint, whereas the application of SA at $1000 \mathrm{mg} \cdot \mathrm{L}^{-1}$ and distillation water of $A$. absinthium, L. vera, and $M$. fistulosa increased oil weight of spearmint. None of the treatments decreased essential oil weight of the mint species.

As a result of loss of oil samples during transportation, we do not have sufficient data to evaluate the effect of treatments on the composition of peppermint and spearmint oil. The essential oil analyses indicated that peppermint oil contained $\alpha$-pinene, $\beta$-pinene, sabinene, myrcene, 1-limonene, 1.8 cineole, paracimene, transsabinenehydrate, 1-menthone, menthofuran, d-isomenthone, b-bourbonene, menthyl acetate, neo-menthol, b-cariophyllene, 1-menthol, pulegone, germacrene-d, and piperitone. The major constituent was L-menthol, which varied from $37 \%$ to $47 \%$, and in most instances, L-menthol was above $41 \%$. This is within the typical range for high-quality peppermint oils (Lawrence, 2007) and is similar to previous reports (Chalchat et al., 1997; Mustiatse, 1985; Rohloff et al., 2005; Zheljazkov and Nielsen, 1996; Zheljazkov

Table 1. Analysis of variance $P$ values for testing the main and interaction effects of species and treatment on dry weight, essential oil weight, and essential oil content. ${ }^{z}$

\begin{tabular}{lccc}
\hline Source of variation & Dry weight & Essential oil weight & Essential oil content \\
\hline Species & $\mathbf{0 . 0 0 9}$ & 0.001 & 0.001 \\
Treatment & $\mathbf{0 . 0 1 6}$ & 0.002 & 0.001 \\
Species $\times$ treatment & 0.538 & $\mathbf{0 . 0 0 1}$ & $\mathbf{0 . 0 0 1}$ \\
\hline
\end{tabular}

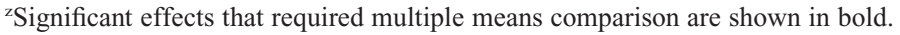

Table 2. Mean dry weight, essential oil content, and essential oil weight from the 25 treatments. $^{\mathrm{z}}$

\begin{tabular}{|c|c|c|c|c|c|}
\hline \multirow[b]{3}{*}{ Treatment } & \multirow{3}{*}{$\begin{array}{c}\text { Dry weight } \\
\text { (g/pot) }\end{array}$} & \multicolumn{2}{|c|}{ Essential oil content } & \multicolumn{2}{|c|}{ Essential oil weight } \\
\hline & & $\overline{M . \times p i p e r i t a}$ & $\overline{\text { M. spicata }}$ & M.×piperita & M. spicata \\
\hline & & \multicolumn{2}{|c|}{$(\%)$} & \multicolumn{2}{|c|}{ (g/pot) } \\
\hline$\overline{\mathrm{MJ}} 10 \mathrm{mg} \cdot \mathrm{L}^{-1}$ & $65.2 \mathrm{bcd}$ & $1.20 \mathrm{c}-\mathrm{h}$ & $0.81 \mathrm{k}-\mathrm{q}$ & $0.84 \mathrm{~b}-\mathrm{g}$ & $0.49 \mathrm{k}-\mathrm{n}$ \\
\hline MJ $100 \mathrm{mg} \cdot \mathrm{L}^{-1}$ & $62.4 \mathrm{~cd}$ & $1.55 \mathrm{a}$ & $0.59 \mathrm{p}-\mathrm{t}$ & $0.96 \mathrm{abc}$ & $0.36 \mathrm{mn}$ \\
\hline $\mathrm{MJ} 1000 \mathrm{mg} \cdot \mathrm{L}^{-1}$ & $67.0 \mathrm{bcd}$ & $1.32 \mathrm{a}-\mathrm{d}$ & $0.61 \mathrm{p}-\mathrm{t}$ & $0.87 \mathrm{~b}-\mathrm{f}$ & $0.441 \mathrm{mn}$ \\
\hline GA3 $10 \mathrm{mg} \cdot \mathrm{L}^{-1}$ & $70.7 \mathrm{bcd}$ & $1.31 \mathrm{bcd}$ & $0.47 \mathrm{t}$ & $0.94 \mathrm{a}-\mathrm{e}$ & $0.34 \mathrm{n}$ \\
\hline GA3 $100 \mathrm{mg} \cdot \mathrm{L}^{-1}$ & $71.3 \mathrm{a}-\mathrm{d}$ & $1.05 \mathrm{e}-\mathrm{i}$ & $0.51 \mathrm{st}$ & $0.80 \mathrm{~b}-\mathrm{h}$ & $0.34 \mathrm{n}$ \\
\hline GA3 $1000 \mathrm{mg} \cdot \mathrm{L}^{-1}$ & $74.6 \mathrm{a}-\mathrm{d}$ & $0.96 \mathrm{i}-\mathrm{m}$ & $0.53 \mathrm{rst}$ & $0.72 \mathrm{c}-\mathrm{i}$ & $0.39 \mathrm{mn}$ \\
\hline $\mathrm{SA} 10 \mathrm{mg} \cdot \mathrm{L}^{-1}$ & $61.5 \mathrm{~d}$ & $1.37 \mathrm{abc}$ & $0.61 \mathrm{o}-\mathrm{t}$ & $0.82 \mathrm{~b}-\mathrm{g}$ & $0.39 \mathrm{mn}$ \\
\hline $\mathrm{SA} 100 \mathrm{mg} \cdot \mathrm{L}^{-1}$ & $68.7 \mathrm{bcd}$ & $1.45 \mathrm{ab}$ & $0.70 \mathrm{n}-\mathrm{t}$ & $0.99 \mathrm{ab}$ & $0.48 \mathrm{k}-\mathrm{n}$ \\
\hline $\mathrm{SA} 1000 \mathrm{mg} \cdot \mathrm{L}^{-1}$ & $83.6 \mathrm{a}$ & $1.18 \mathrm{~d}-\mathrm{h}$ & $0.8 \mathrm{j}-\mathrm{p}$ & $0.95 \mathrm{a}-\mathrm{d}$ & $0.71 \mathrm{~d}-\mathrm{j}$ \\
\hline Achillea millefolium & $68.3 \mathrm{bcd}$ & $1.29 \mathrm{bcd}$ & $0.56 \mathrm{q}-\mathrm{t}$ & $0.94 \mathrm{a}-\mathrm{e}$ & $0.35 \mathrm{mn}$ \\
\hline Ammi majus & $71.4 \mathrm{a}-\mathrm{d}$ & $1.28 \mathrm{~b}-\mathrm{e}$ & $0.64 \mathrm{o}-\mathrm{t}$ & $0.87 \mathrm{~b}-\mathrm{f}$ & $0.49 \mathrm{k}-\mathrm{n}$ \\
\hline Artemisia absinthium & $77.4 \mathrm{ab}$ & $1.32 \mathrm{a}-\mathrm{d}$ & $0.77 \mathrm{k}-\mathrm{q}$ & $0.99 \mathrm{ab}$ & $0.62 \mathrm{~g}-1$ \\
\hline Cymbopogon flexuosus & $76.5 \mathrm{ab}$ & $1.35 \mathrm{a}-\mathrm{d}$ & $0.50 \mathrm{t}$ & $1.18 \mathrm{a}$ & $0.33 \mathrm{n}$ \\
\hline Cymbopogon martinii & $67.7 \mathrm{bcd}$ & $1.27 \mathrm{~b}-\mathrm{e}$ & $0.721-\mathrm{s}$ & $0.90 \mathrm{~b}-\mathrm{e}$ & $0.47 \mathrm{k}-\mathrm{n}$ \\
\hline Chrysanthemum balsamita & $66.7 \mathrm{bcd}$ & $1.28 \mathrm{~b}-\mathrm{e}$ & $0.72 \mathrm{~m}-\mathrm{s}$ & $0.96 \mathrm{abc}$ & $0.47 \mathrm{lmn}$ \\
\hline Hypericum perforatum & $67.8 \mathrm{bcd}$ & $1.24 \mathrm{c}-\mathrm{f}$ & $0.64 \mathrm{n}-\mathrm{t}$ & $0.95 \mathrm{a}-\mathrm{d}$ & $0.38 \mathrm{mn}$ \\
\hline Hyssopus officinalis & $69.3 \mathrm{bcd}$ & $1.15 \mathrm{~d}-\mathrm{h}$ & $0.81 \mathrm{k}-\mathrm{q}$ & $0.79 \mathrm{~b}-\mathrm{h}$ & $0.57 \mathrm{i}-\mathrm{n}$ \\
\hline Lavandula vera & $75.0 \mathrm{abc}$ & $1.04 \mathrm{f}-\mathrm{j}$ & $0.86 \mathrm{j}-\mathrm{n}$ & $0.82 \mathrm{~b}-\mathrm{g}$ & $0.62 \mathrm{~g}-1$ \\
\hline Monarda fistulosa & $76.4 \mathrm{ab}$ & $1.02 \mathrm{f}-\mathrm{j}$ & $0.89 \mathrm{i}-\mathrm{m}$ & $0.76 \mathrm{c}-\mathrm{i}$ & $0.68 \mathrm{e}-\mathrm{k}$ \\
\hline Perilla frutescens & $69.7 \mathrm{bcd}$ & $1.11 \mathrm{e}-\mathrm{i}$ & $0.84 \mathrm{j}-\mathrm{O}$ & $0.77 \mathrm{~b}-\mathrm{h}$ & $0.58 \mathrm{~h}-\mathrm{m}$ \\
\hline Ruta graveolens & $72.7 \mathrm{a}-\mathrm{d}$ & $1.22 \mathrm{c}-\mathrm{g}$ & $0.86 \mathrm{i}-\mathrm{n}$ & $0.96 \mathrm{a}-\mathrm{d}$ & $0.58 \mathrm{~h}-\mathrm{m}$ \\
\hline Satureja pilosa & $71.0 \mathrm{bcd}$ & $1.16 \mathrm{~d}-\mathrm{h}$ & $0.83 \mathrm{j}-\mathrm{p}$ & $0.87 \mathrm{~b}-\mathrm{f}$ & $0.56 \mathrm{i}-\mathrm{n}$ \\
\hline Sideritis scardica & $64.3 \mathrm{bcd}$ & $0.98 \mathrm{~h}-1$ & $0.58 \mathrm{p}-\mathrm{t}$ & $0.67 \mathrm{f}-1$ & $0.35 \mathrm{mn}$ \\
\hline Tanacetum parthenium & $68.1 \mathrm{bcd}$ & $0.77 \mathrm{k}-\mathrm{q}$ & $0.761-\mathrm{r}$ & $0.51 \mathrm{j}-\mathrm{n}$ & $0.53 \mathrm{j}-\mathrm{n}$ \\
\hline Water control & $64.3 \mathrm{bcd}$ & $1.01 \mathrm{~g}-\mathrm{k}$ & $0.67 \mathrm{n}-\mathrm{t}$ & $0.70 \mathrm{~d}-\mathrm{j}$ & $0.40 \mathrm{mn}$ \\
\hline
\end{tabular}

${ }^{\mathrm{z}}$ Within each response, means sharing the same letter are not significantly different.

$\mathrm{MJ}=$ methyl jasmonate; GA3 = gibberellic acid; $\mathrm{SA}=$ salicylic acid. 
et al., 2010a). The spearmint essential oil contained $\alpha$-pinene, $\beta$-pinene, sabinene, myrcene, l-limonene, 1.8 cineole, cis-ocimene, y-terpinene, 3-octyl acetate, 3-octanol, transsabinenehydrate, b-bourbonene, terpinene-4-ol, b-cariophyllene, dihydrocarvone, transdihydrocarvyl acetate, transb-farnesene, $\alpha$-terpineol, geracrene-d, 1-carvone, cis-carvyl acetate, transcarveol, cis-carveol, cis-jasmone, and viridiflorol. The major constituent was L-carvone; in most samples, it was above $65 \%$, which is the expected concentration for this constituent in 'Native' spearmint oil (Bienvenu et al., 1999; Carvalho and Da Fonseca, 2006; Lawrence, 2007; Zheljazkov et al., 2010b).

This study demonstrated that the residual distillation water of some aromatic plant species, a waste product from distillation that is currently released into rivers and streams, may have an effect on crop species and may be used as a tool for increasing essential oil content or essential oil yields of peppermint and spearmint crops. Further research is needed to elucidate the effect of these treatments on essential oil composition and to verify the effects under field conditions.

\section{Literature Cited}

Bienvenu, F., L. Peterson, and J. Edwards. 1999. Native and Scotch spearmint oil production in
Tasmania and Victoria. A report for Rural Industries Research and Development Corporation, Publ. \#99/147, Project \#DAV-101A. Australia. Feb. 2010. <http://www.rirdc.gov.au/ reports/index.htm>.

Carvalho, C.C.C.R. de and M.M.R. Da Fonseca. 2006. Carvone: Why and how should one bother to produce this terpene? Food Chem. 95: 413-422.

Chalchat, J.C., R.P. Garry, and A. Michet. 1997. Variation of the chemical composition of essential oil of Mentha piperita L. during growing time. J. Essent. Oil Res. 9:463-465.

Lawrence, B.M. 2007. Mint: The genus Mentha. CRC Press, Boca Raton, FL.

Mielnik, M.B., S. Sem, B. Egelandsdal, and G. Skrede. 2008. By-products from herbs essential oil production as ingredient in marinade for turkey thighs. LWT Food Sci. Technol. 41:93100.

Mint Industry Research Council. 2009. Dec. 2009. $<$ http://usmintindustry.org/Home/tabid/53/ Default.aspx $>$.

Montgomery, D.C. 2009. Design and analysis of experiments. 7th Ed. Wiley, New York, NY.

Mustiatse, G.I. 1985. Kultura miaty perechnoi (peppermint). Stiintsa, Chisinau, Moldova.

National Agricultural Statistic Service. 2009. June 2009. <http://www.nass.usda.gov/Statistics_by_ State/Oregon/Publications/Field_Crop_Report/ crop\%20reports/01_13an.pdf>.

Rohloff, J., S. Dragland, R. Mordal, and I. Tor-Henning. 2005. Effect of harvest time and drying method on biomass production, essential oil yield and quality of peppermint (Mentha ×piperita L.). J. Agr. Food Chem. 53:4143-4148.

SAS Institute Inc. 2003. SAS OnlineDoc 9.1. SAS Institute Inc., Cary, NC.

Topalov, V.D. 1989. Mentha, p. 372-381. In: Topalov, V.D., I.I. Dechev, and M.S. Pehlivanov. Plant production. Zemizdat Press, Sofia, Bulgaria.

Tucker, A.O. 1992. The truth about mints. Herb Companion 4:51-52.

Tucker, A.O. and D.E. Fairbrothers. 1990. The origin of Mentha xgracilis (Lamiaceae). I. Chromosome numbers, fertility, and three morphological characters. Econ. Bot. 44:183-213.

Zheljazkov, V. and N.E. Nielsen. 1996. Effect of heavy metals on peppermint and cornmint. Plant Soil 178:59-66.

Zheljazkov, V.D., C.L. Cantrell, T. Astatkie, and M.W. Ebelhar. 2010a. Peppermint productivity and oil composition as a function of nitrogen, growth stage, and harvest time. Agron. J. 102: 124-128.

Zheljazkov, V.D., C.L. Cantrell, T. Astatkie, and M.W. Ebelhar. 2010b. Productivity, oil content and composition of two spearmint species in Mississippi. Agron. J. 102:129-133.

Zheljazkov, V.D., C.L. Cantrell, B. Tekwani, and S. Khan. 2008. Content, composition, and bioactivity of the essential oil of three basil genotypes as a function of harvesting. J. Agr. Food Chem. 56:380-385. 